\title{
The Moon's a balloon
}

Henry Gee

Apollo 13. A film directed by Ron Howard. Universal Pictures: 1995.

Lost Moon: The Perilous Voyage of Apollo 13. By Jim Lovell and Jeffrey Kluger. Houghton Mifflin: 1994. Pp. 378. \$22.95. Published in paperback as Apollo 13. Pocket Books, \$6.50; Coronet, £5.99.

The Apollo Adventure: The Making of the Apollo Space Program and the Movie Apollo 13. By Jeffrey Kluger. Pocket Books/Boxtree: 1995. Pp. 199. £8.99 (pbk).

THE most remarkable thing about the Apollo 13 mission is that it got anywhere near the Moon at all. The veteran astronaut Jim Lovell (played by the deservedly ubiquitous Tom Hanks), commander of the ill-starred spacecraft, works out a course correction, by hand, with pencil and paper. Not quite certain of the correct answer, he asks mission control to verify his calculations. More than 200,000 miles away, men in short-sleeved nylon shirts and unfeasibly thick spectacles gather round a console and one of them goes over Lovell's maths - with a slide rule.

The story of Apollo 13 is simply told. On Monday 13 April 1970, while proceeding in a moonwardly direction, an electrical fault sparks an explosion in a tank of liquid oxygen, rupturing the spacecraft's insides. Deprived of much of the oxygen needed for their fuel cells and (let us not forget) breathing, the three astronauts shut down the command module and take refuge in the lunar module, a short-range bicycle built for just

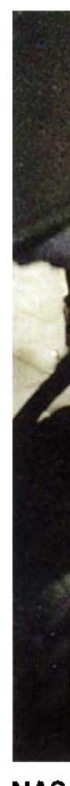

NASA's soft under-belly - Apollo 13 astronauts during lift-off in a scene from the film. Left to right: Bill Paxton (playing Haise), Kevin Bacon (Swigert) and Tom Hanks (Lovell).

Americans. In this political respect, Apollo was a complete success. In that we have not returned, and the sum total of scientific knowledge gained by the Apollo programme was not significantly greater than nil, it was an abject failure. NASA's greatest scientific successes have come, as they always have, from unmanned probes. As Bruce Murray pointed out in his book on the Voyager missions, it is a sad irony that Voyager 2 reached Uranus on the same day that the space-shuttle Challenger exploded after barely clearing the ground. Now, when even the shuttle-delivered Hubble Space Telescope is occasionally upstaged by more advanced telescopes on the ground, module from Woolworth's) Digita the continuing political devotion to the shuttle programme and the space station is a mark of an agency whose starship doesn't quite make warp speed.

This, then, is the real tragedy of the manned space programme, and why the film is so affecting: that so many people, on the ground as much as in the spacecraft themselves, should expend so much loyalty, effort and commitment, and put their lives at risk, to an end that was never more than tawdry and is now completely pointless. That they managed to get as far as the Moon inside what, to modern eyes, looks like an over-engineered tumble-dryer only embellishes their quixotic bravery.

To take the longer view of the confirmed science-fiction reader, the Apollo missions were simply ahead of their time, two (and for those, cosily). Any thoughts of landing on the Moon are cancelled as crew and controllers alike struggle to bring the spacecraft home safely. Which they do, of course.

Not that this foregone conclusion should deter one from seeing Apollo 13, a thoroughly involving story, far from the Boy's Own adventure that one would almost be bound to expect. The universally fine acting, the sharp, documentarystyle direction and (one has to say) attention to period detail hold one's interest throughout. When the astronauts wipe condensation off the windows so they can see the Moon, you are there with them, willing them to come home safely.

But period detail? Surely: this is 1970 , the ycar the Beatles split up (a cause of much angst for one of Lovell's teenage daughters in the film), when even quite normal people wore flared trousers, plastered brown and orange hessian up the walls, and lava lamps were actually in. The film opens with the landing of Apollo 11, as seen on television in the Lovells' lounge, the décor of which is

watches hadn't been invented, Clive Sinclair had still to popularize the electronic calculator, and NASA scientists boasted of a computer so powerful that it could store a million bits of information yet be fitted into any convenient ballroom.

Given such primitive technology, what business did we have even to tip our hats at the Moon? At the time, NASA folk talked publicly of science, exploration and pioneering spirit. When asked by a congressman why, when Apollo 11 had already landed on the Moon, one would need to go back, Hanks (as Lovell) responds that Christopher Columbus had had no such qualms. People talked cheerfully of regular trips to the Moon and the establishment of a permanent lunar base: and yet, so far, barely a minyan has trod the lunar surface, and the Moon has had no return bookings since Apollo 17 in December 1972, more than 20 years ago.

Not that anyone, apart from small children, was under the illusion that the manned space programme was anything other than a dig at the Soviet Union. Of the dozen moonwalkers, all have been like Victorian designs for steam-driven aeroplanes - the miracle being that with Apollo the designs often worked. Perhaps, one day, when we are very much richer and have worked out a genuine rationale for the enterprise, something like the space station will become a viable platform for manned exploration of the Solar System, perhaps even the stars... one day.

Back on Earth, Lost Moon is the book that inspired the film, Lovell's personal account of his part in the space programme, with editorial help from the writer Jeffrey Kluger. Lovell had flown twice in the Gemini missions (the precursor to Apollo) and had orbited the Moon in Apollo 8. The Apollo 13 mission was to have been his swansong, when he would finally set foot on the Moon.

It was not to be, but his personal account of how he made his way into the space programme by way of the US Navy (in which he had been a test pilot) is interesting reading. The book is written like a novel, in the third person, and the better parts remind one of James 
Michener's weighty epic Space (particularly the scenes at the US Navy test centre at Patuxent River, Maryland, which presumably drew on a common fund of experience). Matters sag, somewhat, as Kluger displays the extent of his researches with interminable reconstructed mission-controllathons. Here is one:

"Ten minutes to burn," Haise announced. Shortly afterward he called, "Eight minutes to burn," then "Six minutes to burn," then "Four minutes to burn." Finally Brand, at his Capcom station, took up the call.

"Jim, you are go for the burn, go for the burn."

"Roger, I understand," Lovell said. "We are go for the burn."

Somehow the film manages to convey the technical niceties of the mission without such tedious exegesis. Nevertheless, Lost Moon is packed with information on a mission that NASA would probably rather we forgot about, and jackdaw space enthusiasts will not be deterred by the occasional attempts at literature.

The Apollo Adventure (the book of the film of the book) eschews even that. It is little more than a scrapbook of mission details, accounts of the filming and assorted Apollo miscellany that Lovell and Kluger were unable to cram into the earlier book. These include transcripts of astronauts bitching about their employers, no more interesting than one would expect for them having been classified until recently. The design and production are tacky: the random pepperings of spacecraft schematics would be great were one the kind of person (God forbid) who absolutely has to know the location of every storage compartment in the command module - except that the printing is too indistinct to read. Save your money and see the film instead.

Henry Gee is an assistant editor of Nature.

\title{
Nature lovers and other villains
}

\author{
Stuart L. Pimm
}

\section{Nature's Keepers: The New Science of Nature Management. By Stephen Budiansky. Free Press/Weidenfeld and Nicolson: 1995. Pp. 310. \$25, £18.99.}

ONF judges a book not by its cover but by the quotations that adorn it. Ennobled by the statement on the back of Nature's Keepers that "modern ecological research is providing the tools for effective nature management", ecologists ought to ask for more money. Yet the volume also carries praise from Gregg Easterbrook, author of A Moment on the Earth, a deeply flawed book that spawned a vigorous Internetbased competition this summer to see who could find the most scientific errors per page. So is Nature's Keepers another book trashing science, conveniently timed to appear just as the US Congress is contemplating reversing its long and impressive record of protecting nature? The text is as divided as its cover.

In "the cult of the wild", the book impales nature lovers who revere William Wordsworth, the poet, or Chief Seattle, the American Indian ecological prophet. Wordsworth did not want his daffodils appreciated by the untutored, workingclass hordes that a proposed railroad would bring. And Chief Seattle's famous speech — "Earth does not belong to man, man belongs to Earth" - is a fabrication of a modern film script. $\mathrm{He}$ evidently said nothing about the environment. Debunking myths is wicked fun. It also misses the point. Christmas is still deeply significant to Christians who know that decorated trees are a Victorian import, that 25 December is suspiciously close to the date of pagan winter-solstice rituals and that astronomical explanations for the Star of Bethlehem (comets, supernovae) came in the wrong month of the wrong year. Historically, Amerindians may have exterminated most of the large vertebrates they encountered, but we should not denigrate their modern religious beliefs about the environment.

Next comes "the science (but mostly politics) of nature management". Ecologists are praised for knowing that "disturbance" and "change" typify nature

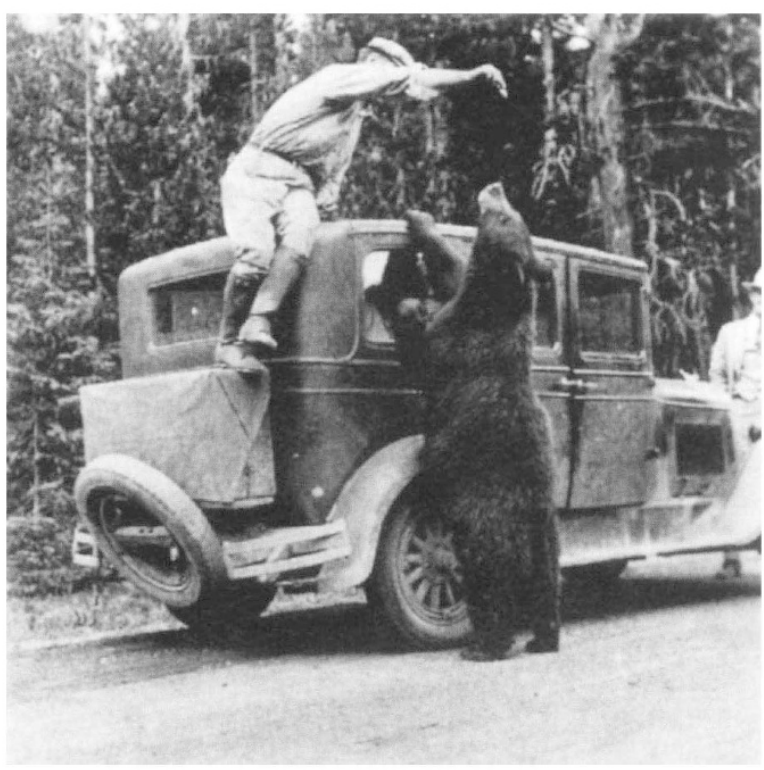

From The Grizzly Bears of Yellowstone: Their Ecology in the Yellowstone Ecosystem, 1959-1992 by J. J. Craighead, J. S. Sumner and J. A. Mitchell. Island, \$100. better than "constancy" and "balance". They will not delight in their characterization as the smart heroes who oppose the ignorant, evil managers of national parks. With hindsight, ecologists might have decided to do things differently at Yellowstone or Tsavo. Nevertheless, those who manage fire or large mammals in parks that are token remnants of the original native ecosystems have awesome tasks to perform.

Finally, we meet the theoreticians, still waiting for a modern Newton to give them a grand synthesis. Budiansky writes at length and fairly accurately about grouse, fisheries, the restoration of oak-savannas and which species one cannot remove from food webs without dire consequences. Those expecting victims will not be disappointed. Edward O. Wilson is described as "a relentless popularizer" whose conclusions "are something closer to politics than science" and as the known collaborator of "misanthropic" Paul Ehrlich, the "over-population guru".

The subject is extinction rates. We are told to be surprised that the observed rate "is not 50,000 species per year, but one species a year". Only those who read footnotes will find that Budiansky derives this estimate from a sample of one in 2,000 species. So the yearly total is in fact 2,000 extinctions - a rate that will surely increase at least tenfold in the coming decades for reasons Budiansky discusses. A yearly rate of 20,000 extinctions is within a factor of three of Wilson's muchderided estimate, yet four orders of magnitude greater than the rate implied in the main text.

The arithmetic also fails when Budiansky discusses the relationship between the number of species an area contains and its size. This is the key concept underpinning predictions of the extinctions that follow habitat losses. He quotes an "unintended parody of the entire concept" in a novel whose hero finds 200 beetles within a square mile, then estimates that within a day's drive there will be 500,000 species. Knowing that species numbers increase under such circumstances in proportion to no more than the one-tenth to one-fifth power of the area, ecologists predict 650 to 2,100 species within a $200-$ mile radius. Far from being a parody, their predictions (unlike the hero's) are reasonable. So too are their estimates of species losses following habitat destruction.

For someone who can write engagingly and some- 